\title{
Bibliography
}

\author{
Special and General
}

\section{Hindu Period.}

Aiyanger, R. V. R. Considerations on Some Aspects of Ancient Indian Polity. Madras 1916. Ali, Yusuf. Life and Labour of the People of India. Lond. 1907.

Beni Prasad, Dr. The State in Ancient India. Allahabad 1928.

Bhandarkar, Dr. D. R. K. Lectures on Ancient History of India Cal. 1919.

- Asoka. Cal. 1925.

-, A Peep into the Early History of India. Cal. 1920.

Bloomfield, M. The Religion of the Veda. Lond. 1896.

Bose, P. N. Survival of Hindu Civilisation.

Davids, Th. W. Rhys. Buddhist India. Lond. 1885.

Dutt, R. C. The Civilisation of India. Lond. 1900.

Fick, R. The Social Organisation in North-East India in Buddha's Times. (Translated by Mitra). Cal. 1920.

Fa-Hien. Record of Buddhist kingdoms; Fa-Hien and His Travels in India. A. D. 399-414. Oxford 1886.

Gosphal, M. Hindu Political Theories. Cal. 1923.

Havell, E. B. The History of the Aryan Rule in India from the earliest to the death of Akbar. Lond. 1918.

Hopkins, W. E. India: Old and New. New York 1901.

Jayasval, K. P. Introduction to Hindu Polity. Cal. 1913.

Law, N. N. Aspects of Ancient Indian Polity. Lond. 1921.

-. Studies in Ancient Hindu Polity. Lond. 1914.

Lefmann, S. Geschichte des alten Indiens.

MacCrindle. Ancient India as deseribed Megasthenes and Arrian. Lond. 1877.

Mahabharata. Translated into English by P. K. Roy. 1919.

Maine, Sir H. J. S. Village Communities in the East and West.

Mazumdar, R. C. Corporate Life in Ancient India. Cal. 1918.

Manava-Dharmasastra. (The Institutes of Manu), Translated by G. C. Haughton. Lond. 1825.

Matthai, J. Village Government in British India. Lond. 1915.

Mookerji, R. K. Nationalism in Hindu Culture. Lond. 1921.

- The Fundamental Unity of India. Lond. 1914.

-. Local Government in Ancient India. Oxford 1920.

Oldenberg, H. Ancient India. 1896.

Pargiter, F. E. Ancient Indian Historical Tradition. Oxford 1922.

Pavgi, N. B. R. Self-Government in India, Vedic and post Vedic. Poona 1918.

Ptolemy, C. Ancient India as described by Ptolemy (Translated by Mc Grindle). Calc. 1885.

Ragozin, Z. A. Vedic India, as embodied in the Rig Veda. Westminster 1894.

Risely, Sir H. The People of India. Lond. 1915.

Sastri, R. S. Evolution in Indian Polity. Calc. 1920.

Schleiden, Hubbe. Indien und die Inder. 1898.

Smith, V. A. Asoka. Oxford 1920.

-. The Early History of India. Oxford 1925.

- The Oxford History of India. Oxford 1919.

Svami, R. Indian Polity in the Times of Manu. 1913. 
Tagore, Rabindranath. Nationalism.

Vandyopadhyaya, P. N. Public Administration in Ancient India. 1916.

Vasu, P. C. Indo-Aryan Polity. 1925.

Watters, T. (Edited) Yuan Chwang's Travels in India, 629-645 A. D. 1904.

Whitehead, Rev. H. Indian Problem in Religion, Education and Politics. Lond. 1924.

Whitney, W. D. Atharva-Veda Samhita. 1905.

-. Harvard Oriental Studies Vol. 787.

Zimmer, H. Altindisches Leben. 1879.

Mohammedan Period.

Abul Fazl. The Akbarnama of Abul-Fazl: History of the Emperor of Akbar to A. D. 1602. (Translated from the Persian H. Beveridge), 1897.

- Ayeen Akbery: Akbar's Regulations for the Government of Hindustan (Translated by F. Gladwin). Lond. 1800. 2 Vols.

Arnold, T. W. The Preaching of Islam. Lond. 1913.

Beni Prasad, Dr. History of Jahangir. Lond. 1922.

Bernier, F. Travels in Hindustan or The History of the Late Revolution of the Dominions of the Great Mogul. From 1655-1661. Cal. 1904.

- Travels in the Mogul Empire A. D. 1656-1668. (Trans. by A. Constable in 1891) 2nd Edition Lond. 1914.

Barve, M. V. R. The Struggle between the Maharattas and the Moghuls. Cal. 1914.

Elliot, H. M. and J. Dowson. The History of India as told by its own Historians. 8 Vols. Lond. 1867/77.

Elphinstone, Hon., M. History of India: Hindu and Mahometan Periods. Lond. 1905.

Farristah, M. K. ibn H. S. History of the Rise of the Mahomedan Power in India till the year A. D. 1612. 4 vols. Cal. 1908.

Holden, E. S. The Mogul Emperors of Hindustan 1398-1707. Westminister 1895.

Khan, G. H. A History of India, 1706-1782. (Translated by Haji Mustafa). Cal. 1904.

Law. N. N. Promotion of Learning in India during Muhammedan Rule by Muhammedans. 1916.

Lyall, Sir A. G. Asiatic Studies. Lond. 1882.

Moreland, W. H. India at the death of Akber. Lond. 1920.

- India from Akber to Aurenzeb. Lond. 1923.

Muhammad ibn Ahmad, Al-biruni. Alberuni's India's account of India, about A. D. 1030. 2 vols. 1881.

Noer, F. A. v. Kaiser Akber. 2 vols. Leiden 1880.

Pinkerton, J. (Edited) A General Collection of the best and most interesting Voyages and Travels in all parts of the World. Lond. 1811. vol. 8.

Poole, S. L. Mediaeval India under Muhammadan rule, A. D. 712-1764. Lond. 1903.

-. Mediaeval India from Contemporary Sources. Bombay 1916.

Beni Prasad, Dr, History of Jahangir. Lond. 1922.

Ranade, M. G. Rise of the Maratha Power. Bombay 1900.

Roe, Sir T. The Embassy of Sir Thomas Roe to the Court of the Great Mogul. 2 vols. Lond. 1899.

Sarkar, J. N. Studies in Mughal India. Cal. 1919.

-. Mughal Administration. Cal. 1920.

- History of Auranzeb. 5 vols. Cal. 1924.

-. Shivaji and his Times. Cal. 1919.

Smith, V. A. Akber, the Great Mogul 1542-1605. Oxford 1920.

Thomas, F. W. Mutual influence of Muhammadans and Hindus. Camb. 1892.

Taverneir, T. B. Travels in India during the 15,16 and 17 Centuries. (Trans. by V. Ball) Edited by W. Crooke (2nd Edition) Lond. 1925. 2 vols. 
Townsend, M. Asia and Europe. Lond. 1911.

Westcott, Rev. G. H. Kabir and the Kabir. Lond. 1907.

Wells, H. G. The Outline of History. Lond.

$$
\text { English Period. }
$$

Anderson, G. British Administration in India. Lond. 1913.

Arbuthnot, Sir A. T. Major General Sir Thomas Munro (a memoir) Lond. 1889.

Aitchison, Sir S. A Collection of Treaties and Sanads. Cal. 1862/72.

Asia. The Oxford Survey of the British Empire. Oxford 1914.

B. Congress Sketches. 1889.

Banerjea, Sir S. N. A Nation in Making. Lond. 1925.

- The Trumpet Voice of India-His Speeches. Madras 1909.

Banerjee, T. B. Indian National Congress. 1885.

Bartlett, Sir E. A. Shall England keep India? Lond. 1886.

Beatson, W. S. India: past and present. Bath. 1890.

Bell, Major E. The Empire in India. Lond. 1865.

Belfour, Lady B. History of Lord Lytton‘s Indian Administration 1876/8. Lond. 1899.

Besant, Dr. A. India: A Nation. 3rd Ed. 1923.

- Home Rule and the Empire (a lecture). 1917.

-. India's Awakening (a lecture). 1908.

-. India's Hour of Destiny. 1918.

Bevan, E. Indian Nationalism. Lond. 1914.

Blackwood, F. J. H. Marquis of Dufferin. Speeches delivered in India 1884-1888. Lond. 1890.

Blunt, W. S. Ideas about India. Lond. 1885.

-. My Diaries. Lond. 1920.

-. India under Ripon (a Private Diary). Lond. 1909.

Bonnerja, W. C. Indian Politics. 1898.

Boulger, D. C. The Story of India. Lond. 1897.

-... India in the 19th century. Lond. 1901.

Briggs, J. India and Europe. Lond. 1857.

-. The Present Land-tax in India. Lond. 1830.

Bright, Rt. H. J. Speech on Legislation and Policy for India. Lond. 1858.

Buchan, J. Lord Minto (a memoir).

Buckle, G. E. The Life of B. Disraeli.

Burke, E. The Works of the Rt. Hon. Burke. Lond. 1872.

-. The Correspondence of Edmund Burke. 4 vols. Lond. 1884.

Campell, Sir G. Modern India. Lond. 1852.

-. India as it may be. Lond. 1853.

-. Memoirs of my Indian Career. 2 vols. Lond. 1893.

Carpenter, W. Empire: in India and elsewhere. Lond. 1900.

Chailley, T. Administrative Problems of India. Lond. 1910.

Chirol, Sir V. India old and new. Lond. 1921.

-. Indian Unrest. Lond. 1910.

Chesney, G. M. India under experiment. Lond. 1918.

Clarke, T. British India and England's Responsibilities. Lond. 1902.

Cobb. C. S. Imperium et Libertas: India and our duties. Lond. 1890.

Colebrooke, Sir T. E. Life of the Hon'ble Mounstuart Elphinstone. Lond. 1884.

Congress: The Report and Proceedings of the Indian National Congress from 1885 to 1918. (33 vols.)

Cotton, Sir H. T. A. New India or India in Transition. Lond. 1904. (1st Edition 1885.)

-. Indian and Home Memories. Lond. 1911. 
Cox, Sir G. W. History of the establishment of the British Rule in India. Lond. 1881. Crawford, A. T. England's Sympathies with the peoples of India. Lond. 1901.

Cunningham, H. S. Earl Canning. Lond. 1891.

-. British India and its Rulers. Lond 1881.

Dar, B. N. Caste System in India (a Paper read at a meeting of Carlyle Society, London. Nov. 4th. 1886).

Digby, W. Prosperous British India. Lond. 1901.

-. India for the Indians and for England. Lond. 1885.

-. Indian Politics in England. Lucknow 1870.

Dilke, Sir C. Greater Britain (A record of travels). Lond. 1885.

-. Problems of Greater Britain. Lond. 1890.

D'oyly, Major-Gen. Sir C. Eight Month's Experience of the Sepoy Revolt in 1857. Blandfold. 1891.

Dutt, R. C. The Economic History of India under Early British Rule. Lond. 1906.

-. India under the Victorian Age. Lond. 1904.

-. India and England. Lond. 1897.

East India Papers. East India Papers. Lond. 1826.

East India Sedition Committee. Report of Committe appointed to investigate Revolutionary Conspiracies in India. Lond. 1918.

Elphinstone, M. Selection from the Minutes and other Writings of the Hon'ble Mounstuart Elphinstone. (Edited by G. W. Forrest.) Lond. 1884.

Farquhar, J. N. Modern Religions of India. Lond. 1924.

Fawcett, Henry M. R. Indian Finance. Lond. 1880.

Fitchett, Rev. W. H. The Tale of the Great Mutiny. Lond. 1907.

Forbes-Mitcell W. Reminiscences of the Mutiny 1857-58. Lond. 1893.

Forrest, Sir G. W. History of the Indian Mutiny. Lond. 1904. 3 vols.

Fuller, Sir J. B. The Empire of India. Lond. 1913.

Ghose, A. Speeches. Chandernagore 1922.

Gleig, Rev. G. R. Memoirs of the Rt. Hon. Warren Hastings. 3 vols. Lond. 1841.

Gokhale, G. K. Speeches. Madras 1920.

-. A Debate on the Awakening of India. 1905.

- Statement before the Royal Commission put in by G. K. Gokhale in 1897.

Hageby, A. K. v. Reisebilder und Skizzen aus dem letzten indischen Kriege 1857-59. (Aus dem Schwedischen). Leipzig 1861.

Hanna, H. B. Indian Problems.

Hardie, J. T. India. Lond. 1909.

Hope, A. R. The Story of the Indian Mutiny. Lond. 1896.

Horne, E. A. The Political System of British India. Oxford 1923.

Holmes, T. R. E. A History of the Indian Mutiny. 5th Ed. Lond. 1913 (1st Ed. 1883.)

Horowitz, J. Indien unter Britischer Herrschaft. Leipzig 1928.

Hume, A. O. Speeches on the Indian National Congress. 1888.

Houghton, B. Bureaucratic Government, A study in Indian Polity. Madras 1913.

Hunter, Sir W. W. History of British India. 2 vols. Lond. 1899.

- The Indian Empire.

- England's work in India. Madras 1880. 1st Edition.

Ilbert, Sir C. P. The Government of India. Oxford 1898.

-. A few Remarks on the Ilbert Bill. Lond. 1883.

Imperial Gazetteer of India. Oxford 1909.

India. A Mohammedan view of the Reform Scheme. 1910.

-. Indien unter England. 1918.

-. Is India worth keeping? Lond. 1878.

-. India's Claim and Britain's Duty. Lond. 1858.

-. An Analysis of the Political History of India. 1779.

-. A Brief view of Slavery on British India. 1841. 
India. The Policy of the Government of British India as exhibited by official documents. Lond. 1839.

-. India: its dangers considered in 1856. Lond. 1858.

-. Government of India, as it has been, as it is and as it ought to be. Lond. 1858.

- Be just to India. Lond. 1861 .

-. India, the Revolt and the Home Government. Lond. 1856.

Indian Nationalist. The Indian War of Independence. Lond. 1909.

India Office. Indian Office Records-Range 9 (Secret Comm. Cons.)

Indian Politics. A Collection of Essays and Addresses. Madras 1886.

Indian Revolt. Causes of the Indian Revolt. 1857.

Innes, Lieut. General McLeod. The Sepoy Revolt. Lond. 1897. (2nd Ed.)

Lilly, W. S. India and its Problems. Lond. 1902.

Lecture. How we tax India. 1857.

Lovett, Sir, V. A History of the Indian Nationalist Movement Lond. 1921. (3rd Ed.)

Ludlow, J. M. British India. 2 vols. Lond. 1858.

Lyall, Sir A. C. Rise and Expansion of the British dominion in India Lond. 1894.

Kale, V. G. Gokhale and Economic Reforms. Cal. 1889.

Kaye, Sir J. W. History of the Mutiny. 6 vols. Lond. 1888.

- History of the Administration of the East India Company. Lond. 1853.

Keene, H. G. History of India. 2 vols. Lond. 1893.

Keith, A. B. Speeches and Documents on Indian Policy. 2 vols. Oxford 1922.

Kelkar, N. C. A Passing Phase of Politics. 1907.

Kennedy, H. A. The Story of the Empire.

Khan. Sir Syed A. The Causes of the Indian Revolt. 1873.

-. The Present State of Politics. Allahabad 1888.

Khan, S. A. An Unrest in India. 1907.

-. India of Today. 1908.

Khan, Sir Agha. India in Transition. Lond. 1918.

Khandekar, D. G. India in 1906. 1907.

Krieck, E. Menschenformung. (Teubner) Leipzig.

Kumaraswami, A. K. Esays in National Idealism.

Mac Carthy, J. A History of our own Times. 4 vols. Lond. 1882.

Mac Donald, T. R. The Government of India. Lond. 1920.

- The Awakening of India. Lond. 1910.

Mackenzie, D. W. The Awakening of India. N. Y. 1917.

Mazumder, A. C. Indian National Evolution. Madras 1918.

Malabari, B. M. The Indian Problems. 1894.

Malcolm, Sir J. The Political History of India, 2 vols. Lond. 1826.

-. Life of Lord Clive. 3 vols. Lond. 1836.

Martin, R. M. The Indian Empire.

-. The Rise and Progress of the Indian Mutiny. 1859.

- (edited) The Despatches, Minutes and Correspondence of Marquess Wellesley during His administration. Lond. 1837.

Metcalfe, Lord. Selections from the Papers of Lord Metcalfe. Lond. 1855.

- Papers and Correspondence of Lord Metcalfe. (Edited by John William Kaye). Lond.

Milburn, R. R. G. England and India. Lond. 1918.

Mill, J. S. Considerations on Representative Government. Lond. 1861.

-. India - a Memorandum on Liberty. (1st edition, 1869). Lond. 1913.

Mill and Wilson. History of British India. 8 vols. Lond. 1888.

Miller, W. Unrest and Education in India. Lond. 1911.

Minto, Speeches of Earl of Minto. Lond. 1911.

Morley, Viscount, J. Indian Speeches 1907-1909. Lond. 1909.

- Speeches on Indian Affairs. Madras 1917.

-. Burke. Lond. 1888. 
Morley, Viscount, J. Recollections. 2 vols. Lond. 1917.

-. Life of R. Cobden. Lond. 1896.

Morrison, Sir, T. Imperial Rule in India. Lond. 1889.

-. The Economic Transition in India. Lond. 1921.

-. New Ideas in India. Lond. 1907.

Muir, R. The Making of British India. Manchester 1923.

- The Expansion of Europe. N. U. 1917.

Murdoch, J. India: past and present. Madras 1903.

-. India's needs. Madras 1886.

Muter, Mrs. My Reccollections of the Sepoy Revolt, 1857-58. Lond.

Naoroje, Dadabhai. Poverty and un-British Rule in India. Lond. 1901.

Natesan. What India wants. Madras 1917.

-. India's Goal. Madras 1917.

Nivedita (Sister). The Civic and National Ideals. Madras 1911.

O'Donnell, C. P. The Causes of Present Discontent in India. Lond. 1908.

-. The Failure of Lord Curzon. Lond. 1903.

Pal, B. C. The Spirit of the Indian Nationalism. Lond. 1910.

-. Speeches of Bepin Chandra Pal. Madras 1907.

-. Responsible Government. 1917.

-. Nationality and Empire. 1916.

Pannikkar, K. M. Indian Nationalism. Lond. 1920.

Pimblett, W. M. How the British won India. Lond. 1893.

Pitt, F. W. (Edited). Incidents in India and memories of the Mutiny. Lond. 1896.

Prekh, C. L. Eminent Indians on Indians Politics. 1892.

Rai, Lajpat. The Call to Young India. N. Y.

-. Reflections on the Political Situation in India. 1917.

-. The Story of my Deportation. 1908.

Ranade, M. G. Social Reform. 1900.

-. Essays on Indian Economics. 1889.

Ratcliffe, S. K. Sir W. Wedderburn and the Indian Reform Movement. Lond. 1923.

Reinsch, P. S. Intellectual and Political Currents in the far East. Lond. 1911.

Robiert, Lord. Forty-one Years in India (New Ed. in one Volume) Lond. 1898.

Robsnson, G. F. S. Marquis of Ripon-Speeches 1880-1882. Cal. 1882.

Rus eell, W. H. My Diaries in India. 2 vols. Lond. 1860.

Sam lson, J. India-- past and present. Lond. 1890.

Sarkar, H. K. Revolutions in Bengal. Cal. 1923.

Seeley, Sir J. R. The Expansion of England. (First Pocket Edition). Lond. 1925.

Shore, Sir F. J. Notes on Indian Affairs. Lond. 1837.

Showers, C. L. A missing chapter of the Indian Mutiny. Lond. 1888.

Sidgwick, F. R. The Indian Mutiny of 1857. Lond. 1909.

Singh. St. N. India and the War. 1918.

Strachey, Sir J. India: its Administration and Progress. Lond.

Tagore, Sir R. N. Greater India. Lond. 1921.

-. Nationalism. Lond. 1917.

Temple, Sir R. India in 1880 . Lond. 1881.

Thompson, E. T. The Other Side of the Medal. Lond. 1925.

Tilak, B. G. Tilak's Message to his Countrymen. 1917.

-. His Speeches and Writings. Madras 1919.

Townsend, M. Asia and Europe. Lond. 1911.

Torrens, Mac W. Empire in Asia-How we came by it. (A Book of Confessions). Lond. 1872 .

Tract. British Rule in India. Tract No. 1. Lond. 1886.

Trotter, L. J. History of India under Queen Victoria. 2 vols. Lond. 1886.

-. History of India. Lond. 1899. 
Valbezan, E. de. England and India. Lond. 1883.

Vambery, A. The Coming Struggle for India. Lond. 1885.

Vandyopadha, D. N. India's National Builders. Cal. 1919.

Vasu, B. N. Why India is heart and soul with Great India. 1914.

-. The Illusions of New India. 1916.

Wadia, A. S. N. Reflections on the Problems of India. 1913.

Webb, M de P. Advance, India! Lond. 1913.

Wedderburn, Sir W. A. O. Hume, Father of the Indian National Congress. Lond. 1913.

Wellesley, Marquess. The Despatches, Minutes and Correspondence. Lond. 1837.

Wellock, W. India's Awakening. Lond. 1922.

Wilberforce, R. G. An unrecorded Chapter of the Indian Mutiny. Lond. 1896.

Wilks, Lieut. Colonel Mark. Historical Sketches of the South of India. Lond. 1810. 3 vols.

Williams, M. Modern India and the Indians. Lond. 1879.

Wood, Sir E. The Revolt in Hindustan. Lond. 1908.

Yusuf, Ali. The Making of India. Lond. 1925. 